\title{
Recent advances and future directions in soils and sediments research
}

\author{
Philip N. Owens • Zhihong Xu
}

Received: 20 July 2011 / Accepted: 20 July 2011 /Published online: 4 August 2011

(C) Springer-Verlag 2011

\section{Introduction}

In 2010, the Journal of Soils and Sediments (JSS) reached a milestone: its $10^{\text {th }}$ anniversary. This prompted us to think about where the academic community has come in its understanding of the behaviour of soils and sediments within landscapes. The rapid growth of the journal and the number of papers published in it, and other related journals, suggests, probably correctly, that there is much interest in the topics of soils and sediments.

In the January 2011 editorial (Xu and Owens 2011), we presented an overview of some of the main developments in the past 10 years and provided some future directions of JSS for 2011 and beyond. In that editorial we indicated that a more comprehensive editorial would be published in the journal on the recent advances and future directions of soils and sediments research. The following sections are presented to fulfill this commitment and start a dialogue with the journal subject editors, authors and readers in these important areas of soils and sediments research.

The dawn of the next decade of JSS is a good time to reflect on progress to-date and, more importantly, to consider where research needs to go in the years ahead; a

P. N. Owens $(\bowtie)$

Environmental Science Program and Quesnel River Research

Centre, University of Northern British Columbia,

3333 University Way,

Prince George, BC V2N 4Z9, Canada

e-mail: owensp@unbc.ca

\section{Z. Xu $(\bowtie)$}

Environmental Futures Centre and School of Biomolecular and Physical Sciences, Griffith University,

170 Kessels Road,

Nathan, Brisbane, QLD 4111, Australia

e-mail: zhihong.xu@griffith.edu.au time of rapid environment change, a time of rapid population growth, and a time when society is increasingly looking to science to provide the understanding (and solutions) to the problems that we face.

\section{Historical development of the Journal of Soils and Sediments}

Before we move into the particular sections below, it is timely to have a historical perspective of JSS establishment and development over the past decade (2001-2010). Here we would like to separate the 10 years into two periods: the first five years (2001-2005) involved the establishment of JSS, whereas the second five years (2006-2010) involved the consolidation and rapid expansion of JSS. In the 20012005 period, JSS published four issues per year, with a total of 149 peer-reviewed research and review articles as well as 65 editorials and commentaries published. Of these, there were $73(49.0 \%)$ articles in the Soils area, $65(43.6 \%)$ in the Sediments area, and $11(7.4 \%)$ in the Intercompartment area involving both soils and sediments research. Since the start of the second period in 2006, one of us (Xu) has become the Editor-in-Chief for Soils, together with the other two Editorsin-Chief: Prof. Förstner (Sediments) and Prof. Salomons (Intercompartment) who retired from JSS at the end of 2010 (Xu and Owens 2010). JSS published four issues each year in 2006 and 2007 (in total 66 research and review articles), six issues each year in 2008 and 2009 (106 articles), and eight issues in 2010 (152 articles), with a total of 324 research and review articles as well as 61 editorials and commentaries published in the second five year period of JSS. In this period 2006-2010, JSS published 190 articles in the Soils area (58.6\%), 113 in the Sediments area (34.9\%), and 21 in the Intercompartment area (6.5\%). 
With the first Impact Factor (IF) for the journal in 2007 of 4.373 (59 articles published in 2005 and 2006, and cited in 2007 for calculating the 2007 IF), published in the Journal Citation Reports by Thomson Reuters (Hollert et al. 2008), JSS was ranked at the top position among the 30 journals in the subject category of Soil Science according to the 2007 IF. This has been followed by the subsequent JSS IF of 2.797 for 2008 (74 articles published in 2006 and 2007, and cited in 2008; ranked 2 of the 31 journals in Soil Science), 2.613 for 2009 (93 articles published in 2007 and 2008, and cited in 2009; ranked 3 of the 31 journals in Soil Science), and 2.574 for 2010 (108 articles published in 2008 and 2009, and cited in 2010; ranked 3 of the 32 journals in Soil Science). In addition, JSS also received the first 5 -year IF of 2.358 for 2010, recently published in the Journal Citation Reports by Thomson Reuters. We are pleased to note that despite only 10 years of publication since 2001, and thus being a relatively young journal, JSS has maintained its position as one of the top three journals in Soil Science for the past 4 years (2007-2010) according to the published IF of Thomson Reuters. This occurred at a time of growing competition from more established journals and a rapid increase in the number of articles published by JSS; from 59 for 2005-2006 to 108 for 2008-2009.

In 2011, we restructured JSS into the two major areas of Soils and Sediments, with $\mathrm{Xu}$ continuing as the Editorin-Chief for Soils, and Owens becoming the Editor-in-Chief for Sediments. In the first five of the eight issues published in 2011, JSS published a total of 79 research and review articles by early July 2011 . Thus the prediction is that more articles will be published in JSS in 2011 than in any previous year. Perhaps more relevant is the huge increase in the number of manuscripts submitted to JSS, which is likely to be $>500$ in 2011. This increase, especially in the Soils area, partly reflects the high IFs of JSS within the Soil Science category of Journal Citation Reports; thus JSS is an obvious and very visible journal choice for the soils community. Historically, research on sediments has tended to be published in the geomorphology, hydrology and environmental science literature. Slowly, the profile of JSS is increasing in the sediments community. We anticipate that JSS will continue to attract an increasing number of submissions and publish more papers from the sediments community in the coming years, especially since the areas of Soils and Sediments are closely linked in the context of combating the global climate change challenge and in addressing increasing environmental issues around the world at basin and regional scales.

\section{Soils research}

There have been a number of editorials and review papers published in JSS on the trends, challenges and develop- ments in soils research within forest ecosystems for the past five years (Chen and Xu 2006, 2008, 2010; Xu et al. 2009). Currently, JSS Soils area consists of five subject sections:

(1) Soil organic matter dynamics and nutrient cycling;

(2) Global change, environmental risk assessment, and sustainable land use;

(3) Remediation and management of contaminated or degraded lands;

(4) Ecotoxicology; and

(5) Soil and landscape ecology.

Global challenges such as climate change have continued to attract growing interest and indeed increasing numbers of submissions and publications in Soils Section 1 (e.g. Blumfield et al. 2006; Huang et al. 2008; Pan et al. 2008; Xu et al. 2008; Sun et al. 2010), Section 2 (e.g. Ge et al. 2008; Zheng et al. 2008; Ibell et al. 2010; Liu et al. 2010; Xing et al. 2010) and Section 5 (e.g. He et al. 2008, 2009; Zhang et al. 2009a, b; Curlevski et al. 2010). Local and regional environmental issues have been addressed in all the five Soils sections, with increasing numbers of submissions and publications in Soils Section 2 (e.g. Burton et al. 2010; Chen et al. 2010; Jiang et al. 2010; Sigua and Coleman 2010), Section 3 (e.g. Liu et al. 2008; Wang et al. 2010) and Section 4 (e.g. Li and Wong 2010; Li et al. 2010).

\subsection{Soils and climate change}

Climate change has been one of the greatest challenges confronting all the people of the world, and attracted much attention and efforts from both the scientific community and the public in combating this truly global challenge. Climate change, particularly rising atmospheric carbon dioxide $\left(\mathrm{CO}_{2}\right)$ and global warming, has been well established in the literature (Xu and Chen 2006; Xu et al. 2009; Frank et al. 2010; Lacis et al. 2010; Schiermeier 2010) and this pattern is projected to intensify in the coming decades (Xu et al. 2009; Doak and Morris 2010; Zhao and Running 2010; Crimmins et al. 2011; Min et al. 2011). However, the impact of climate change, particularly complex atmospheric $\mathrm{CO}_{2}$, temperature and water interactions, on plant photosynthesis and tree growth remains elusive (Xu et al. 2009; Jung et al. 2010; Piao et al. 2010; Schiermeier 2010). Plant photosynthesis is an important biological process, subject to $\mathrm{CO}_{2}$ or water limitation $(\mathrm{Xu}$ et al. 2009). Recent research findings (Helliker and Richter 2009; Mahecha et al. 2010) have highlighted that there is a global convergence towards an optimum temperature of $21.4^{\circ} \mathrm{C}$ at photosynthesizing leaves within forest canopies during the growing season. Moreover, there is also a global convergence in temperature sensi- 
tivity of respiration in terrestrial ecosystems (including tropical, subtropical, temperate and boreal forest ecosystems) (Mahecha et al. 2010). Despite the global temperature convergence for plant photosynthesis at the leaf level (Helliker and Richter 2009) and for respiration at the ecosystem level (Mahecha et al. 2010), there is a strong relationship between photosynthesis and respiration in terrestrial ecosystems (Mahecha et al. 2010). This highlights the importance of plant photosynthesis in driving the dynamic $\mathrm{CO}_{2}$ exchange between the atmosphere and the terrestrial ecosystems, and hence the feedbacks between the changing climate and the terrestrial carbon (C) cycle at both local and global scales.

\subsection{Soil carbon and nutrient dynamics}

Terrestrial ecosystems respond non-linearly to climate change with multiple factors over long periods (Scheffer et al. 2009; Dillon et al. 2010; Doak and Morris 2010; Drake and Griffen 2010; Sun et al. 2010), and can have tipping points or critical boundaries at which a sudden shift to a contrasting dynamic regime might occur (Rockström et al. 2009; Scheffer et al. 2009; Dillon et al. 2010; Doak and Morris 2010; Drake and Griffen 2010). Significantly, more C is stored in the world's soils than in the above-ground biomass and atmosphere (Davidson and Janssens 2006; Fontaine et al. 2007; Gruber and Galloway 2008; Heimann and Reichstein 2008; Piao et al. 2009). Soil C dynamics and N cycling are closely linked, important biogeochemical processes underpinning the positive feedbacks between terrestrial ecosystems and global warming (Davidson and Janssens 2006; Gruber and Galloway 2008; Heimann and Reichstein 2008; Schulze et al. 2009; Xu et al. 2009). In the past decade, there have been significant and exciting developments in testing and applying advanced chemical and bio-molecular techniques for unravelling soil $\mathrm{C}$ and $\mathrm{N}$ cycling processes in terrestrial ecosystems, such as those of stable isotope methods (Blumfield et al. 2004; Bengtson and Bengtsson 2007; Burton et al. 2007; Strand et al. 2008; Xu et al. 2009), nuclear magnetic resonance (NMR) spectroscopy (Mathers et al. 2000; Mao et al. 2002; Chen et al. 2004; Fontaine et al. 2007; Xu et al. 2009), and bio-molecular approaches (He et al. 2005, 2006, 2007; Bastias et al. 2007; Di et al. 2009). In the first application of ${ }^{14} \mathrm{~N}-\mathrm{NMR}$ to soil humic acid (HA) studies, it was discovered that there was the surprising existence of inorganic nitrate- $\mathrm{N}$ in soil HA, with the HA nitrate- $\mathrm{N}$ closely related to soil $\mathrm{N}$ availability and rather responsive to ecosystem management (Mao et al. 2002). The nature of the HA nitrate-N is not yet known, but it is biologically related and highly sensitive to ecosystem management and environmental changes (Xu et al. 2009).

\subsection{Soil microbes in $\mathrm{C}$ and nutrient cycling}

Recent literature reviews on greenhouse gas emissions (Liu and Greaver 2009; Schulze et al. 2009) and terrestrial C and $\mathrm{N}$ cycles (Gruber and Galloway 2008; Heimann and Reichstein 2008; Xu et al. 2009) have highlighted that soil microbial populations (Mitchell et al. 2009) play a central role in regulating the major greenhouse emissions of $\mathrm{CO}_{2}$ (Bond-Lamberty et al. 2007; Arnone et al. 2008; Bowman et al. 2009; Dorrepaal et al. 2009), methane $\left(\mathrm{CH}_{4}\right)$ (Raghoebarsing et al. 2006; Dunfield et al. 2007; Kennedy et al. 2008; Megonigal and Guenther 2008), and nitrous oxide $\left(\mathrm{N}_{2} \mathrm{O}\right)$ (Horz et al. 2004; Leininger et al. 2006; Di et al. 2009; Erguder et al. 2009; Martens-Habbena et al. 2009), particularly in the context of climate change and management options for reducing greenhouse gas emissions (Di et al. 2009; Ravishankara et al. 2009; Schulze et al. 2009) and increasing C sequestration in terrestrial ecosystems (Magnani et al. 2007; Houlton et al. 2008; Lewis et al. 2009; Reich 2009; Rotenberg and Yakir 2010). Labile soil $\mathrm{C}$ and $\mathrm{N}$ pools and dynamics are more sensitive to climate change (Davidson and Janssens 2006; Fontaine et al. 2007; Arnone et al. 2008; Trumbore and Czimczic 2008; Dorrepaal et al. 2009) and management regimes (Mao et al. 2002; Magnani et al. 2007; Di et al. 2009), and closely linked to the greenhouse gas emissions (Di et al. 2009; Liu and Greaver 2009; Schulze et al. 2009), although more recalcitrant soil $\mathrm{C}$ and $\mathrm{N}$ pools (Davidson and Janssens 2006; Fontaine et al. 2007; Trumbore and Czimczic 2008; Xu et al. 2009) are important for soil C sequestration in terrestrial ecosystems. The recent work (e.g. Di et al. 2009) on ammonia-oxidizing bacteria (AOB) and archaea (AOA) has highlighted that despite the large number and abundance of AOA in agricultural soils nitrification is driven by $\mathrm{AOB}$ rather than by $\mathrm{AOA}$, and $\mathrm{AOB}$ is much more sensitive and responsive to management practices. Overall, there have been few studies in testing, developing and applying both advanced chemical technologies and innovative bio-molecular approaches for quantifying important soil $\mathrm{C}$ and $\mathrm{N}$ cycling processes and their interactions with both climate change and management options (Ambebe and Dang 2009; Xu et al. 2009).

\section{Sediments research}

It can be argued that academic research on sediments is increasing; both in volume and in breadth. This statement is demonstrated by several recent (in academic terms) initiatives including, but not limited to:

- the European Sediment Network (SedNet);

- the International Sedimentation Initiative (ISI); 
- the International Commission on Continental Erosion (ICCE);

- the International Association for Sediment Water Science (IASWS); and

- the World Association of Sedimentation and Erosion Research (WASER).

Coupled with these initiatives is a series of publications that focus on sediment research. There are several useful reviews that consider the history of these initiatives and publications, and some of the developments made. For example, Petticrew (2009) reviews developments made by IASWS since 1976 as documented in over 500 publications, and Fig. 1 shows some of the themes and topics that have been addressed. In many respects, Fig. 1 encapsulates the main themes addressed in JSS, albeit described by different phrases, such as: sediment quality and impact assessment; physical and biogeochemical processes; hillslope and river basin sediment dynamics; sediment-ecology interactions; and sediment management. This overlap in research areas is not entirely surprising given the role played by key individuals in both organizations (e.g. Förstner 1977, 2002). The following sections consider some of the recent developments in these themes and offer some future research directions, although both are far from exhaustive.

\subsection{Sediment quality and impact assessment}

One of the core areas of sediment research has been the quality of the sediment (mainly from a chemical perspective) and the impact of "contaminated" sediment on the environment. This comes from an increasing realization that

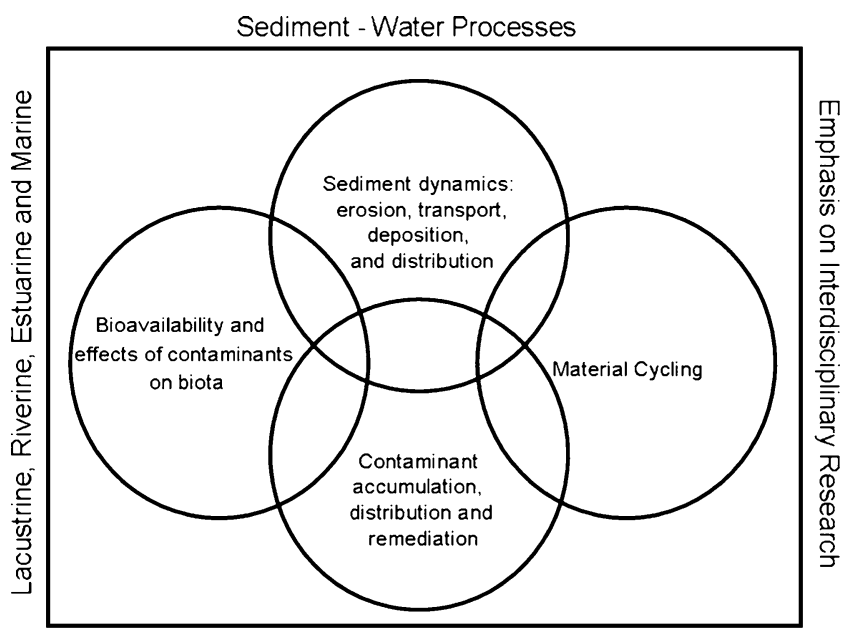

Sampling Methods and Analytical Techniques

Fig. 1 The dominant themes addressed by IASWS over the last 30 years as documented in $>500$ publications. The inclusion of topics surrounding the box is implicit throughout all themes (from Petticrew (2009), reproduced with permission of CSIRO Publishing) sediments act as a vector and reservoir of anthropogenic contaminants. Muir and Howard (2006) estimate that there are 8.4 million substances commercially available at present. As such, there is much research on ways to identify and measure contaminants, and to assess their impacts. The sections below consider some of these developments; other aspects are considered in Section 4.2.

\subsubsection{Analytical techniques and protocols}

A continuing area of research is likely to be ways to improve analysis of sediments and associated chemicals. This demand comes from a growing list of synthetic chemicals within the environmental and a need for greater precision and accuracy of measurement for assessment and regulation purposes. As such, there will be a constant drive to improve analytical methods, including, for example, the coupling of different techniques (i.e. "hyphenated techniques") such as the use of high performance liquid chromatography — inductively coupled plasma — mass spectrometry (HPLC-ICP-MS). These advances can be made through developments in full computerization of instrumental control and advances in engineering, thus enabling linkage interfaces between different separation and detection instruments (Parkinson and Dust 2010). Despite such advances, sample collection and preparation are crucial to maintain consistency and preserve the integrity of the samples under investigation (Parkinson and Dust 2010). Too often, the ways in which samples are collected, stored and prepared are less than ideal, and indeed sometimes inadequate. Despite excellent advances in analytical techniques, more emphasis needs to be placed on ensuring adequate sampling (including the use of appropriate statistical design; e.g. Church et al. 1987), storage (e.g. Phillips and Walling 1995) and preparation (e.g. Condron and Newman 2011; Reid et al. 2011) protocols; instruments will always give values, but are these values meaningful in terms of what information they are providing about the real environment?

\subsubsection{In-situ field methods}

The development of instruments that are able to measure properties in the field-i.e. field-portable, in situ equipment -will likely receive increasing interest. Good examples of this include equipment to measure radionuclide and metal contents in soils and sediments within the field (e.g. He and Walling 2000), and the in-situ measurement of sediment particle size and shape in aquatic systems. In the case of the latter, use of equipment such as the Laser In-Situ Scattering and Transmissometry (LISST) within waterbodies has greatly improved our understanding of the transport of composite particles and associated contaminants within 
channel (e.g. Williams et al. 2007) and floodplain (e.g. Thonon et al. 2005) environments, and particle movement and settling within estuarine and marine environments (e.g. Braithwaite et al. 2010). Techniques for in-situ, real-time analysis of inorganic and organic chemicals are also showing potential (Parkinson and Dust 2010), but clearly there is need for further developments in this area.

\subsubsection{Sediment impacts on ecosystem and human health}

One area that does merit further attention, is the link between sediment and human health. While there is a considerable body of research on the impacts of sediment on aquatic ecosystems (mainly in terms of aquatic organisms like invertebrates and fish: Bilotta and Brazier 2008; Hallare et al. 2011; Kemp et al. 2011), there is fairly limited research on the impacts of sediment on humans. The indirect link between sediment-associated contaminants and human health has been known for a long time in terms of the role of sediment as a component within the food-chain (i.e. habitat for organisms lower in the food-chain), but the direct link has received less attention. Perhaps the largest body of information has come from research on the link between airborne particulates (e.g. $\mathrm{PM}_{2.5}$ ) and human health, in terms of respiratory and other health problems. Most of this work has been undertaken in urban and periurban areas (e.g. Ostro et al. 2006; Taylor and Owens 2009; Jiménez et al. 2010), although other studies have been undertaken near agricultural and mining sites (e.g. Csavina et al. 2011). Recent work has also demonstrated the link between sediment-associated pathogens and human health (e.g. Droppo et al. 2010). The direct role of sediment quantity (e.g. $\mathrm{PM}_{2.5}$ ) and composition/quality (e.g. metals, radionuclides, pathogens) on human health and well-being is, therefore, likely to be a growing area of research.

\subsection{Physical and biogeochemical processes}

Process-based research tends to be at the small- to mediumscale. In part, this is due to the detailed level of observation or measurement required for the detection of the interactions between physical, chemical and biological processes. Process-based research will always be central to a scientific discipline because it provides the basic understanding which is utilized by the other parts of the discipline (i.e. sediment quality and impact assessment, hillslope and river basin sediment dynamics, sediment-ecology interactions, sediment management).

\subsubsection{Sediment-water interface}

In aquatic systems (i.e. freshwater, lacustrine, estuarine, marine) the boundary between deposited sediment and the overlying water column will always be critical. Indeed, the boundary between two media/components of a system (particle-solution, freshwater-saltwater, hillslope-channel) is often the most important, and complex, to understand. Research on physical and biogeochemical processes at the sediment-water interface is likely to remain one of the most important sediment research areas. This interface is key in terms of controlling the mobilization of aqueous sediment, and in regulating chemical exchanges between sediments and porewaters and the overlying water. Recent developments include understanding the role that micro-organisms play in stabilizing the deposited sediment. For example, studies (e.g. Garcia-Aragon et al. 2011) have demonstrated the role of periphyton, biofilms and extracellular polymeric substances (EPS) in stabilizing channel bed sediment from erosion and resuspension, thereby limiting the remobilization of contaminated sediment. Indeed Gerbersdorf et al. (2011) argue that such process understanding should be part of sediment quality assessment. Much of this work on the hydrodynamic and biogeochemical processes operating at the sediment-water interface has involved the use of experimental facilities, such as flumes and within laboratories (e.g. Rex and Petticrew 2008; Garcia-Aragon et al. 2011). A challenge facing researchers is to undertake such work in the field in order to confirm the laboratory-based results in more realistic settings.

\subsubsection{Sediment-chemical interactions}

An understanding of the processes that control the interactions between sediments and chemicals is central to our ability to understand and mitigate contaminated sediment dynamics in aquatic systems. Thus there is a considerable body of research concerned with examining the fractionation and speciation of chemicals associated with sediment (e.g. Tallberg et al. 2009; Sutherland 2010; Condron and Newman 2011; Reid et al. 2011), and the persistence of chemicals and compounds in deposited sediments (e.g. Byrne et al. 2010; Tamtam et al. 2011). Studies have also investigated the role of microbial activity in the sorption of chemicals to sediment, and how this may change due to variations in, for example, temperature and redox (e.g. Huang et al. 2011). Further research is likely to focus on improving our understanding of chemical sorption and desorption to sediment under changing environmental conditions, including the role of changing flow regimes such as floods (Wölz et al. 2010), and the role of thermodynamic and kinetic processes.

\subsection{Hillslope and river basin sediment dynamics}

\subsubsection{Sediment fluxes in river basins and coastal environments}

Sediment dynamics within landscapes may have the longest history within academic sediment research. Soil erosion on 
hillslopes and sediment transport in rivers has been investigated for many decades (e.g. Middleton 1930; Hjulstrom 1935; Einstein 1950). For example, there was a rapid expansion of research on soil erosion and sediment loss from agricultural fields due to the "Dust Bowl" crisis in the USA in the 1930s. More recent developments are trying to link sediment dynamics on hillslopes with those in river channels and in coastal environments (Salomons 2005). The coupling of terrestrial, freshwater and coastal environments has developed from the recognition that water, sediment and chemicals flow between these environments. As a physical rule, flows have been down-slope and downriver, towards the global ocean, but anthropogenic activities now mean that water and materials move in complex patterns, often with transfers between river basins. Much of this need for spatially integrated coupling has been driven by legislation (such as the EU Water Framework Directive) and the need to address problems at the downstream end of river basins, such as sedimentation in harbours and estuaries (e.g. Netzband et al. 2002) and in sensitive environments such as barrier reef systems (e.g. Nunny et al. 2006), by adopting a river basin-scale approach (Owens 2005a). For example, in Australia there has been much research on rivers that supply sediment and chemicals to the Great Barrier Reef (e.g. McCulloch et al. 2003), which has required research to follow sediment from source to sink, and to quantify intermediate storage elements (e.g. Amos et al. 2009). The renewed interest in understanding sediment fluxes in river basins has also been prompted by the realization-although Earth scientists have known this for decades - that sediment fluxes are responsible for delivering chemical elements, in particular nutrients and $\mathrm{C}$, to the global ocean (Milliman and Farnsworth 2011), and are therefore an important component of global environmental change (including coastal eutrophication and global climate change).

\subsubsection{Sediment response to disturbance}

Another major growth area in research has been to investigate how sediment and associated chemical fluxes respond to disturbances and pertubations, which can be both natural and anthropogenic in origin (e.g. Walling and Fang 2003; Syvitski et al. 2005; Middelkoop et al. 2010; Batalla and Vericat 2011). Generally, most research to date has tended to consider each element of change - such as the impact of mining, or reservoir construction or climate change - in relative isolation. However, in reality, most landscapes are affected by multiple stressors which may have cumulative and synergistic effects (Owens et al. 2010). The assessment of how landscapes respond to present and future "cumulative effects" (Gunn and Noble 2009) may represent one of the greatest challenges facing researchers, and is likely to require interdisciplinary thinking and collaboration.

\subsubsection{Sediment tracing and fingerprinting}

Given the increasing recognition that sediment can be a major aquatic problem and is an important vector for associated contaminant and nutrient transport (Förstner and Owens 2007), there is growing interest in trying to determine where the sediment has come from and how it moves through aquatic systems (i.e. from headwaters to the coastal zone). Consequently, there has been a growth in the number of studies concerned with sediment tracing and fingerprinting. Much of the early tracer work utilized environmental fallout radionuclides, such as caesium-137 $\left({ }^{137} \mathrm{Cs}\right)$ and unsupported lead-210 $\left({ }^{210} \mathrm{~Pb}\right.$ un $)$. One could argue that the use of these radionuclides is now wellestablished-although Parsons and Foster (2011) have recently questioned this, by casting doubt on some of the underlying assumptions of, for example, ${ }^{137} \mathrm{Cs}$ - and that most investigations are of the case-study type. Scientific developments are presently focussing on testing additional radionuclides, such as beryllium-7 $\left({ }^{7} \mathrm{Be}\right)$ and thorium-234 $\left({ }^{234} \mathrm{Th}\right)$ (e.g. Blake et al. 1999; Saari et al. 2010), and in developing new tracers, such as rare earth elements (REE) and natural and artificial fluorescence (e.g. Polyakov and Nearing 2004; Granger et al. 2007, 2011; Stevens and Quinton 2008; Spencer et al. 2011). Many of these newer tracers are showing considerable promise, particularly for tracing sediment movement on hillslopes, although further refinement and testing are required to prove their suitability at medium to large spatial scales such as the landscape and river basin scales, and at the interface between freshwater and brackish/saltwater environments.

Similarly, "sediment fingerprinting" is unquestionably a major growth area in sediment dynamics research, in part because the approach is able to address, often simultaneously, both scientific understanding and management decision-making needs. Recent developments have focused on improving some of the statistical and modeling aspects of the approach (e.g. Collins et al. 2010a, b), in addition to testing new "fingerprint" properties such as colour parameters, DNA, and total and compound-specific stable isotopes (e.g. Mahler et al. 1998; McConnachie and Petticrew 2006; Granger et al. 2007; Gibbs 2008; Martínez-Carreras et al. 2010) so as to fingerprint the origin of both the inorganic and organic components of sediment. Some further research is, however, needed to test the robustness of the fingerprinting approach, including improvements in developing procedures to account for tracer property uncertainty within the statistical and modeling stages; often the uncertainties associated with sediment source results are not reflecting the real-world 
situation, and can be misleading. Furthermore, there is a pressing need to examine the conservative nature of the fingerprint properties; at present, a "black-box" approach is typically used whereby there is little understanding of the processes affecting sediment properties between upstream sources and downstream sampling location (Fig. 2).

\subsection{Sediment-ecology interactions}

There is a long history which has shown how fine-grained sediment and associated contaminants and nutrients can be detrimental to aquatic organisms (for recent reviews see: Bilotta and Brazier 2008; Jones et al. 2011; Kemp et al. 2011). Indeed, sediment toxicity is often assessed using aquatic organisms (Hallare et al. 2011). Some recent developments have focused of other aspects of ecological interactions with sediments. A few examples are given below.

\subsubsection{Link between vegetation and sediment dynamics}

The feed-back between vegetation and sediment redistribution has been at the forefront of soils and sediments research for several decades and continues to be one of the largest research areas in soil science, physical geography and geomorphology research groups. Even today, vegetation is usually identified as a primary factor in controlling soil erosion (e.g. De Baets et al. 2011), channel bank erosion (e.g. Eaton and Giles 2008) and sediment redistribution within the landscape (e.g. LópezVicente et al. 2011). The recent explosion of interest in the effects of wildfires on soil erosion, and sediment and chemical transport through river channels (e.g. Owens et al. 2006; Petticrew et al. 2006; Blake et al. 2010; Smith et al. 2011) is another example of this type of work, albeit from a natural disturbance-response perspective.

\subsubsection{In-channel sediment-vegetation dynamics}

Several studies have documented the role of in-channel vegetation in controlling sediment deposition and stabilizing the channel bed. Recent flume-based and field studies (e.g. Wharton et al. 2006; Heppell et al. 2009; Harvey et al. 2011; Jones et al. 2011; Salant 2011) have also demonstrated that both macrophytes and periphyton are important in controlling sediment deposition and resuspension within river channels. According to Harvey et al. (2011) "physical-biological interactions and resulting effects on sediment and nutrient redistribution are arguably some of the principal drivers of ecological function and hydrogeomorphic evolution of aquatic systems..... and deserve more study".

\subsubsection{The role of aquatic organisms as biogeomorphic agents}

Perhaps some of the most exciting recent and on-going research has investigated how aquatic organisms, such

Fig. 2 Black-box approach adopted by many sediment fingerprinting studies, in which a direct connection between sources and downstream sediment is often assumed. In reality there may be important processes between upstream sources and downstream sediment collection which could influence the behaviour of fingerprint properties, thereby compromising their effectiveness or negating their use

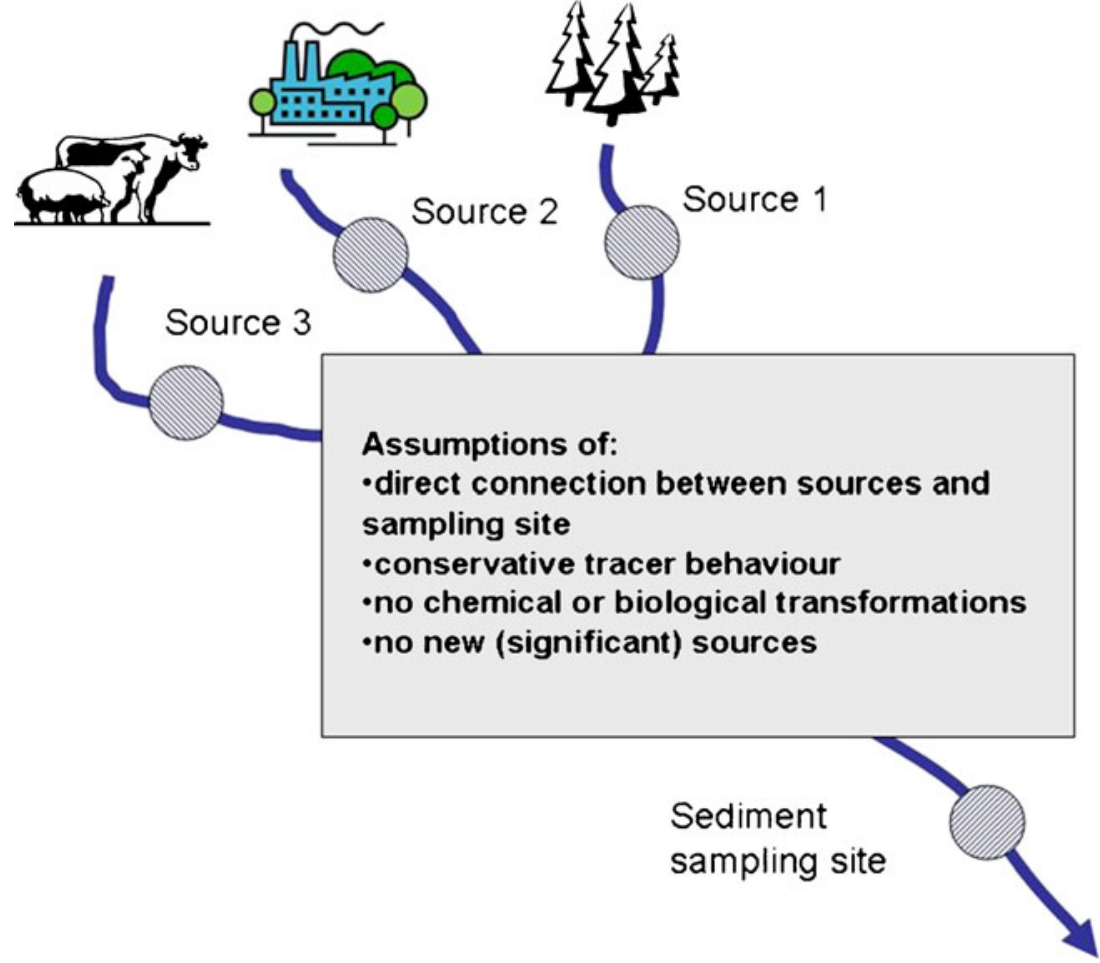


as fish and macro-invertebrates, influence the environment in which they live (De Vries 2011). Good examples of this include work on the role of salmonids on disturbing channel bed sediment to make redds (nests). Much of this work has focused on the Pacific coast of North America, where salmon returns from the Pacific Ocean to natal streams and rivers are of epic proportions. In British Columbia, ca. 30 million sockeye salmon returned to the Fraser River alone in 2010. Such migrations represent one of the few significant natural, upstream movements of biomass and nutrients in river systems. Rex and Petticrew (2008) and Petticrew and Albers (2010) have demonstrated how organic material derived from rotting salmon interact with fine-grained sediment - much of which is derived by suspension from the channel bed during redd construction by the salmon - to create composite particles or flocs. These flocs, which are larger and heavier than ambient suspended sediment, settle onto the channel bed, thereby enabling important marine-derived nutrients to be retained within the channel environment in headwater streams, as opposed to being flushed downstream. Similarly, Hassan et al. (2008) have shown how spawning salmon are important in terms of bedload transport and in modifying the channel morphology through the construction of redds. Such work clearly shows how aquatic organisms regulate their environment so as to maintain optimum (physical and chemical) habitats.

\subsection{Sediment management}

There has been an increase in the amount of science to address management issues (Petticrew 2009). In many respects this comes from shifts in the needs of national and international funding bodies, which are often driven by concerns associated with financial accountability (from the tax payer) and by the need to address real and present environmental concerns (from local and national governments). While there use to be a difference between "applied" research (usually funded by industry and government) and "blue-sky" research (usually funded by national research councils), the distinction is now less clear and the latter is often driven by the requirements of governments and industry. While this inevitably has some drawbacks, there are many positive aspects (e.g. increased outreach and engagement with the public) and opportunities (e.g. collaboration with colleagues from other disciplines, such as the social and health sciences).

\subsubsection{Using sediment archives to inform management decisions}

It is well known that changes in land use and land management, and river use and management influence sediment and associated contaminant dynamics within aquatic systems (Walling and Fang 2003; Owens 2005b; Förstner and Owens 2007). What is less clear is the magnitude of such changes, and how such changes may be manifest in the future. In many situations, the instrumental record provided by monitoring networks is often of insufficient length to answer such questions. In this context, the record contained within sedimentary environments contains much promise, both from a scientific and a policy-development perspective. Sedimentary records contained within floodplain, reservoir, lake and salt marsh environments, among others, can be used to provide information on: (a) "background" conditions (i.e. fluxes and concentrations) prior to a disturbance (e.g. land use change, climate change, river dredging activities); (b) the magnitude and rate of response to this disturbance; and (c) the likely trajectory into the future given anticipated conditions (e.g. Owens and Walling 2003; Walling et al. 2003; Bindler et al. 2011). A good example of how this can be used to inform policy is provided by Foster et al. (2011) who show how lake and reservoir sediments can be used to reconstruct sediment yields and thereby identify the likely reduction required to return to background (or desirable) levels (Fig. 3). Further research is needed to identify "background" conditions (Bindler et al. 2011) and to improve the temporal resolution available from such archives.

\subsubsection{Buffering features to regulate sediment and associated chemical fluxes}

Another growth area of research, that has been driven by a management perspective, is the role of natural (e.g. wetlands, floodplains, riparian forests) and artificial (e.g. constructed riparian vegetative strips) buffering features in the landscape to regulate material fluxes (e.g. water, sediment and chemicals). Such features have typically been used to regulate flows between hillslopes and river

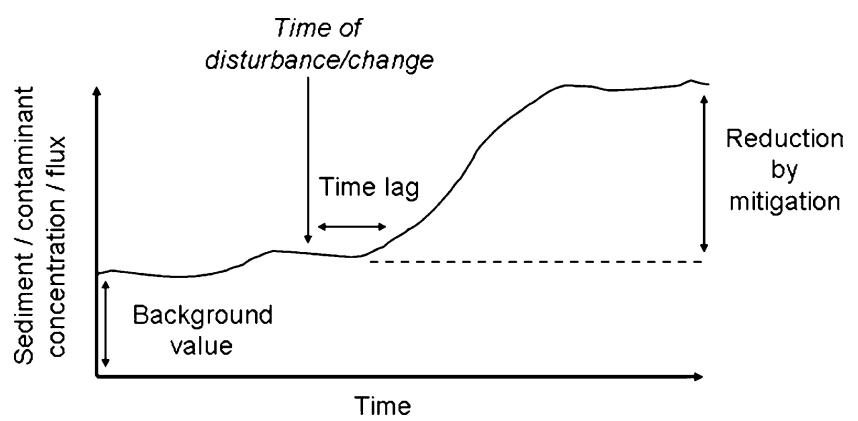

Fig. 3 The concept of using paleolimnological reconstruction of sediment and contaminant dynamics within river basins and other aquatic systems to inform management and policy decision-making (modified from Foster et al. 2011) 
channels, often with the aim of trying to improve surface water quality. Many studies (e.g. Owens et al. 2007; Clinton 2011) have investigated the efficiency and design of buffer zones. While such features are no doubt useful, in many situations they may not be in optimal locations or of suitable design (e.g. Dosskey et al. 2011). Much guidance on buffer design and location has been based on research undertaken in temperate environments, such as the UK and USA. Such guidance may not be entirely appropriate in contrasting environments, such as those that have peak surface flows (during annual periods of snowmelt) over frozen soils and when vegetation cover is minimal (e.g. Steward et al. 2011). Further research is required to evaluate buffer features in such contrasting conditions. In addition, much of the research has focused on relatively small sections of the landscape, such as river reaches, and the effectiveness in reducing sediment loads at larger spatial scales has been questioned (e.g. Verstraeten et al. 2006). Thus, research is needed to assess the role of buffer features at the larger scale, such as the landscape and river basin scales. This may require a combination of field testing and spatial extrapolation techniques, such as modeling and GIS (e.g. Moriasi et al. 2011). Finally, we lack a good understanding of the resilience of such features to environmental disturbances (e.g. large-scale forest harvesting and mining) and to future environmental changes (e.g. anticipated changes in precipitation and land cover); we are planning for the present situation, rather than thinking of what might be needed in the near future.

\subsubsection{Decision support frameworks}

Ultimately, the management of natural resources (i.e. water, soil, sediment) comes down to making decisions, often underpinned by a good understanding of the main processes involved. As such, there has been a considerable amount of work on designing appropriate decision support frameworks to aid with decision making. Such frameworks have used different approaches, including conceptual (White and Apitz 2008; Granger et al. 2010), risk-based (Apitz 2008a) and adaptive (Apitz 2008b; Owens 2009) structures, among others. These all have various advantages and disadvantages. A current trend seems to be for more ecosystem services-based approaches (e.g. Apitz 2011). Frameworks which are inclusive, more realistic, and wholistic are likely to offer consider promise, especially if they are transparent for all to see the mechanisms and principles behind them. Challenges still remain in translating such frameworks into products that are usable by managers and policy-makers. This requires dialogue and understanding, and the ability to embrace new ideas and approaches.

\section{Conclusion}

This article has identified some of the main areas of current research and has illustrated areas where further research is needed. Much of this recent progress has come about because of a shift towards more collaborative, and intraand inter-disciplinary research; something at the heart of the Journal of Soils and Sediments. The review above is far from complete, maybe only touching the tip of the iceberg. We hope, however, that it will encourage researchers to think carefully about what is needed in order to make real progress in our understanding of soils and sediments within landscapes, and ultimately how we can protect them and the ecosystems in which they reside, particularly in the context of climate change, which is expected to intensify with significant impacts on both soils and sediments in the coming decades.

\section{References}

Ambebe TF, Dang QL (2009) Low moisture availability inhibits the enhancing effect of increased soil temperature on net photosynthesis of white birch (Betula papyrifera) seedlings grown under ambient and elevated carbon dioxide concentrations. Tree Physiol 29:1341-1348

Amos KJ, Croke JC, Timmers H, Owens PN, Thompson C (2009) The application of caesium-137 measurements to investigate floodplain deposition in a large semi-arid catchment in Queensland, Australia: a low-fallout environment. Earth Surf Process Landforms 34:515-529

Apitz SE (2008a) Is risk-based, sustainable sediment management consistent with European Policy. J Soils Sediments 8:461-466

Apitz SE (2008b) Adaptive management principles and sediment management. J Soils Sediments 8:359-362

Apitz SE (2011) Conceptualizing the role of sediment in sustaining ecosystem services: Sediment-ecosystem regional assessment (SEcoRA). Sci Total Environ. doi:10.1016/j.scitotenv.2011.05.060

Arnone JA, Verburg PSJ, Johnson DW, Larsen JD, Jasoni RL et al (2008) Prolonged suppression of ecosystem carbon dioxide uptake after an anomalously warm year. Nature 455:383-390

Bastias BA, Anderson IC, Xu ZH, Cairney JWG (2007) RNA- and DNA-based profiling of soil fungal communities in native Australian eculypt forest and adjacent Pinus elliottii plantation. Soil Biol Biochem 39:3108-3114

Batalla RJ, Vericat D (2011) An appraisal of the contemporary sediment yield in the Ebro basin. J Soils Sediments. doi:10.1007/s11368-011-0378-8

Bengtson P, Bengtsson G (2007) Rapid turnover of DOC in temperate forests accounts for increased $\mathrm{CO} 2$ production at elevated temperatures. Ecol Lett 10:783-790

Bilotta GS, Brazier RE (2008) Understanding the effects of suspended solids on water chemistry and aquatic biota. Water Res 42:2849 2861

Bindler R, Rydberg J, Renberg I (2011) Establishing natural sediment reference conditions for metals and the legacy of long-range and local pollution on lakes in Europe. J Paleolimnol 45:519-531

Blake WH, Walling DE, He Q (1999) Fallout beryllium-7 as a tracer in soil erosion investigations. Appl Radiation Isotope 51:599-605 
Blake WH, Theocharopoulos SP, Skoulikidis N, Clark P, Tountas P, Hartley R, Amaxidis Y (2010) Wildfire impacts on hillslope sediment and phosphorus yields. J Soils Sediments 10:671-682

Blumfield TJ, Xu ZH, Mathers NJ, Saffigna PG (2004) Decomposition of post-harvest, ${ }^{15} \mathrm{~N}$-labelled hoop pine residues in subtropical Australia. Soil Sci Soc Am J 68:1751-1761

Blumfield TJ, Xu ZH, Prasolova NV, Mathers NJ (2006) Effect of overlying windrowed harvest residues on soil carbon and nitrogen in hoop pine plantations of subtropical Australia. J Soils Sediments 6:243-248

Bond-Lamberty B, Peckham SD, Ahl DE, Gower ST (2007) Fire as the dominant driver of central Canadian boreal forest carbon balance. Nature 450:89-92

Bowman DMJS, Balch JK, Artaxo P, Bond WJ, Carlson JM et al (2009) Fire in the Earth system. Science 324:481-484

Braithwaite KM, Bowers DG, Smith WAMN et al (2010) Observations of particle density and scattering in the Tamar Estuary. Marine Geol 277:1-10

Burton J, Chen CR, Xu ZH, Ghadiri H (2007) Gross nitrogen transformations in adjacent native and plantation forests of subtropical Australia. Soil Biol Biochem 39:426-433

Burton J, Chen CR, Xu ZH, Ghadiri H (2010) Soil microbial biomass, activity and community composition in adjacent native and plantation forests of subtropical Australia. J Soils Sediments 10:1267-1277

Byrne P, Reid I, Wood PJ (2010) Sediment geochemistry of streams draining abandoned lead/zinc mines in central Wales; the Afon Twymyn. J Soils Sediments 10:683-697

Chen CR, Xu ZH (2006) On the nature and ecological functions of soil soluble organic nitrogen (SON) in forest ecosystems. J Soils Sediments 6:63-66

Chen CR, Xu ZH (2008) Analysis and behaviour of soluble organic nitrogen in forest soils. J Soils Sediments 8:363-378

Chen CR, Xu ZH (2010) Forest ecosystem responses to environmental changes: the key regulatory role of biogeochemical cycling. J Soils Sediments 10:210-214

Chen CR, Xu ZH, Mathers NJ (2004) Soil carbon pools in adjacent natural and plantation forests of subtropical Australia. Soil Sci Soc Am J 68:282-291

Chen X, Zhang LM, Shen JP, Xu ZH, He JZ (2010) Soil type determines the abundance and community structure of ammoniaoxidizing bacteria and archaea in flooded paddy soils. J Soils Sediments 10:1510-1516

Church M, McLean MG, Wolcott JF (1987) River bed gravels: sampling and analysis. In: Thorne CR, Bathurst JC, Hey RD (eds) Sediment Transport in Gravel Bed Rivers. Wiley, Chichester, pp 43-88

Clinton BD (2011) Steam water responses to timber harvest: riparian buffer width effectiveness. Forest Ecol Manage 261:979-988

Collins AL, Zhang Y, Walling DE, Grenfell SE, Smith P (2010a) Tracing sediment loss from eroding farm tracks using a geochemical fingerprinting procedure combining local and genetic algorithm optimisation. Sci Total Environ 408:54615471

Collins AL, Walling DE, Webb L, King P (2010b) Apportioning catchment scale sediment sources using a modified composite fingerprinting technique incorporating property weightings and prior information. Geoderma 155:249-261

Crimmins SM, Dobrowski SZ, Greenberg JA, Abatzoglou JT, Mynsberge AR (2011) Changes in climatic water balance drive downhill shifts in plant species' optimum elevations. Science 331:324-327

Csavina J, Landazuri A, Wonaschutz A, Rine K, Rheinhamer P, Barbaris B, Conant W, Saez AE, Betterton EA (2011) Metal and metalloid contaminants in atmospheric aerosols from mining operations. Water Air Soil Poll. doi:10.1007/s11270-011-0777-x
Condron LM, Newman S (2011) Revisiting the fundamentals of phosphorus fractionation in soils and sediments. J Soils Sediments 11:830-840

Curlevski NJA, Xu ZH, Anderson IC, Cairney JWG (2010) Soil fungal communities differ in native mixed forest and adjacent Araucaria cunninghamii plantations in subtropical Australia. J Soils Sediments 10:1278-1288

Davidson EA, Janssens IA (2006) Temperature sensitivity of soil carbon decomposition and feedbacks to climate change. Nature 440:165-173

De Baets S, Poesen J, Meersmans J, Serlet L (2011) Cover crops and their erosion-reducing effects during concentrated flow erosion. Catena 85:237-244

De Vries P (2011) Salmonid influences on rivers: a geomorphic fish tail. Geomorphology. doi:10.1016/j.geomorph.2011.04.040

Di HJ, Cameron KC, Shen JP, Winefield CS, O'Callaghan M, Bowatte S, He JZ (2009) Nitrification driven by bacteria and not archaea in nitrogen-rich grassland soils. Nature Geosci $2: 621-624$

Dillon ME, Wang G, Huey RB (2010) Global metabolic impacts of recent climate warming. Nature 467:704-706

Doak DF, Morris WF (2010) Demographic compensation and tipping points in climate-induced range shifts. Nature 467:959-961

Dorrepaal E, Toet S, van Logtestijn RSP, Swart E, van de Weg MJ et al (2009) Carbon respiration from subsurface peat accelerated by climate warming in the subarctic. Nature 460:616-619

Dosskey MG, Helmers MJ, Eisenhauer DE (2011) A design aid for sizing filter strips using buffer area ratio. J Soil Water Conserv 66:29-39

Drake JM, Griffen BD (2010) Early warning signals of extinction in deteriorating environments. Nature 467:456-459

Droppo IG, King K, Tirado SM, Sousa A, Wolfaardt G, Liss SN, Warren LA (2010). Assessing riverine sediment-pathogen dynamics: implications for the management of aquatic and human health risk. In: Banasik K, Horowitz AJ, Owens PN, Stone M, Walling DE (eds) Sediment Dynamics for a Changing Future. IAHS Publ. 337:245-250

Dunfield PF, Yuryev A, Senin P et al (2007) Methane oxidation by an extremely acidophilic bacterium of the phylum Verrucomicrobia. Nature 450:879-882

Eaton BC, Giles TR (2008) Assessing the effect of vegetation-related bank strength on channel morphology and stability in gravel-bed streams using numerical models. Earth Surf Process Landforms 34:712-724

Einstein HA (1950) The bed-load function for sediment transportation in open channel flows. United States Department of Agriculture SCS Tech Bull 1026, USDA

Erguder TH, Boon N, Wittebolle L, Marzorati M, Verstrate W (2009) Environmental factors shaping the ecological niches of ammoniaoxidizing archaea. FEMS Microbiol Rev 33:855-869

Fontaine S, Barot S, Barre P, Bdioui N, Mary B, Rumpel C (2007) Stability of organic carbon in deep soil layers controlled by fresh carbon supply. Nature 450:277-280

Förstner U (1977) Metal concentrations in freshwater sediments natural background and cultural effects. In: Golterman HL (ed) Interactions between Sediments and Freshwater: Proceedings of the First International Symposium. Dr. W Junk Publishers, The Hague, pp 94-103

Förstner U (2002) Sediments and the European Water Framework Directive. J Soils Sediments 2:54

Förstner U, Owens PN (2007) Sediment quantity and quality issues in river basins. In: Westrich B, Förstner U (eds) Sediment Dynamics and Pollutant Mobility in Rivers. Springer, Berlin, pp 1-15

Foster IDL, Collins AL, Naden PS, Sear DA, Jones JI, Zhang Y (2011) The potential for paleolimnology to determine historic sediment delivery to rivers. J Paleolimnol 45:287-306 
Frank DC, Esper J, Raible CC, Buntgen U, Trouet V, Stocker B, Joos F (2010) Ensemble reconstruction constraints on the global carbon cycle sensitivity to climate. Nature 463:527-530

Garcia-Aragon J, Droppo IG, Krishnappan BG, Trapp B, Jaskot C (2011) Erosion characteristics and floc strength of Athabasca River cohesive sediments. J Soils Sediments 11:679-689

Ge Y, Zhang JB, Zhang LM, He JZ (2008) Long-term fertilization regimes affect bacterial community structure and diversity of an agricultural soil in northern China. J Soils Sediments 8:43-50

Gerbersdorf SU, Hollert H, Brinkmann M, Wieprecht S, Schüttrumpf H, Manz W (2011) Anthropogenic pollutants affect ecosystem services of freshwater sediments: the need for a "triad plus $\mathrm{x}$ " approach. J Soils Sediments. doi:10.1007/s11368-011-0373-0

Gibbs M (2008) Identifying source soils in contemporary estuarine sediments: A new compound-specific isotope method. Estuar Coast 31:344-359

Granger SJ, Bol R, Butler PJ, Haygarth PM, Naden P, Old G, Owens PN, Smith BPG (2007) Processes affecting transfer of sediment and colloids, with associated phosphorus, from intensively farmed grasslands: tracing sediment and organic matter. Hydrol Process 21:417-422

Granger SJ, Bol R, Anthony S, Owens PN, White SM, Haygarth PM (2010) Towards a holistic classification of diffuse agricultural water pollution from intensively managed grasslands on heavy soils. Adv Agron 105:83-115

Granger SJ, Bol R, Hawkins JMB, White SM, Naden PS, Old GH, March JK, Bilotta GS, Brazier RE, Maclead CJA, Haygarth PM (2011) Using artificial fluorescent particles as tracers of livestock wastes within an agricultural catchment. Sci Total Environ 409:1095-1103

Gruber N, Galloway JN (2008) An Earth-system perspective of the global nitrogen cycle. Nature 451:293-296

Gunn J, Noble BF (2009) Integrating cumulative effects in regional strategic environmental assessment frameworks: lessons from practice. J Environ Assess Policy Manag 11:267-290

Hallare A, Seiler T-B, Holler H (2011) The versatile, changing, and advancing roles of fish in sediment toxicity assessment - a review. J Soils Sediments 11:141-173

Harvey JW, Noe GB, Larsen LG, Nowacki DJ, McPhillips LE (2011) Field flume reveals aquatic vegetation's role in sediment and particulate phosphorus transport in a shallow aquatic ecosystem. Geomorphology 126:297-313

Hassan MA, Gottesfeld AS, Montgomery DR, Tunnicliffe JF, Clarke GKC, Wynn G, Jones-Cox H, Poirier R, MacIssac E, Herunter H, MacDonald SJ (2008) Salmon-driven bed load transport and bed morphology in mountain streams. Geophys Res Lett 35:L04405

He Q, Walling DE (2000) Calibration of a field-portable gamma detector to obtain in situ measurements of the Cs-137 inventories of cultivated soils and floodplain sediments. Appl Radiation Isotope 52:865-872

He JZ, Xu ZH, Hughes J (2005) Pre-lysis washing improves DNA extraction from forest soils. Soil Biol Biochem 37:2337-2341

He JZ, Xu ZH, Hughes J (2006) Molecular bacterial diversity of a forest soil under different residue management regimes in subtropical Australia. FEMS Microbiol Ecol 55:38-47

He JZ, Shen J, Zhang L, Zhu Y, Zheng Y et al (2007) Quantitative analyses of the abundance and composition of ammoniaoxidizing bacteria and ammonia-oxidizing archaea of a Chinese upland red soil under long-term fertilization practices. Environ Microbiol 9:2364-2374

He JZ, Zheng Y, Chen CR, He YQ, Zhang LM (2008) Microbial composition and diversity of an upland red soil under long-term fertilization treatments as revealed by culture-dependent and culture-independent approaches. J Soils Sediments 8:349-358

He JZ, Ge Y, Xu ZH, Chen CR (2009) Linking soil bacterial diversity to ecosystem functions. J Soils Sediments 9:547-554
Heimann M, Reichstein M (2008) Terrestrial ecosystem carbon dynamics and climate feedbacks. Nature 451:289-292

Helliker BR, Richter SL (2009) Subtropical to boreal convergence of tree-leaf temperatures. Nature 454:511-514

Heppell CM, Wharton G, Wotton JAC, Bass JAB, Roberts SE (2009) Sediment storage in the shallow hyporheic of vegetated river reaches. Hydrol Process 23:2239-2251

Hjulstrom F (1935) Studies of the morphological activity of rivers as illustrated by the River Fryis. Bull Geol Inst Uni Uppsala 25:221-527

Hollert H, Heinrich AB, Seiler TB (2008) The first impact factor. J Soils Sediments 8:203-205

Horz HP, Barbrook A, Field CB, Bohannan BJM (2004) Ammoniaoxidizing bacteria respond to multifactorial global change. Proc Natl Acad Sci USA 101:15136-15141

Houlton BZ, Wang YP, Vitousek PM, Field CB (2008) A unifying framework for dinitrogen fixation in the terrestrial biosphere. Nature 454:327-U34

Huang ZQ, Xu ZH, Chen CR, Blumfield TJ (2008) Soil nitrogen mineralization and fate of $\left({ }^{15} \mathrm{NH}_{4}\right)_{2} \mathrm{SO}_{4}$ in field-incubated soil in a hardwood plantation of subtropical Australia: the effects of mulching. J Soils Sediments 8:389-397

Huang LD, Du ST, Fan L, Lin XY, Wang HL, Zhang YS (2011) Microbial activity facilitates phosphorus adsorption to shallow lake sediments. J Soils Sediments 11:185-193

Ibell P, Xu ZH, Blumfield TJ (2010) Effects of weed control and fertilization on soil carbon and nutrient pools in an exotic pine plantation of subtropical Australia. J Soils Sediments 10:10271038

Jiang YM, Chen CR, Xu ZH, Liu YQ (2010) Soil soluble organic carbon and nitrogen pools under mono- and mixed-species forest ecosystems in subtropical China. J Soils Sediments 10:10711081

Jiménez E, Linares C, Martínez D, Díaz J (2010) Role of Saharan dust in the relationship between particulate matter and short-term daily mortality among the elderly in Madrid (Spain). Sci Total Environ 408:5729-5736

Jones JI, Collins AL, Naden PS, Sear DA (2011) The relationship between fine sediment and macrophytes in rivers. River Res Applic. doi:10.1002/rra.1486

Jung M, Reichstein M, Ciais P et al (2010) Recent decline in the global land evapotranspiration trend due to limited moisture supply. Nature 467:951-954

Kemp P, Sear D, Collins A, Naden P, Jones (2011) The impacts of fine sediment on riverine fish. Hydol Process 25:1800-1821

Kennedy M, Mrofka D, von der Borch C (2008) Snowball Earth termination by destabilization of equatorial permafrost methane clathrate. Nature 453:642-645

Lacis AA, Schmidt GA, Rind D, Ruedy RA (2010) Atmospheric $\mathrm{CO}$ 2: principal control knob governing Earth's temperature. Science 330:356-359

Leininger S, Urich T, Schloter M, Schwark L, Qi J et al (2006) Archaea predominate among ammonia-oxidizing prokaryotes in soils. Nature 442:806-809

Lewis SL, Lopez-Gonzalez G, Sonke B et al (2009) Increasing carbon storage in intact African tropical forests. Nature 457:1003-1006

Li WC, Wong MH (2010) Effects of bacteria on metal bioavailability, speciation, and mobility in different metal mine soils: a column study. J Soils Sediments 10:313-325

Li XF, Huang YZ, Ma YB, Sun JW, Cui HJ (2010) Leaching impacts Ni toxicity differently among soils but increases its predictability according to nitrification assay. J Soils Sediments 10:579-589

Liu JX, Peng SJ, Faivre-vuillin B, Xu ZH, Zhang DQ, Zhou GY (2008) Erigeron annuus (L.) Pers., as a green manure for ameliorating soil exposed to acid rain in Southern China. J Soils Sediments 8:452-460 
Liu JX, Zhou GY, Zhang DQ, Xu ZH, Duan HL, Deng Q, Zhao L (2010) Carbon dynamics in subtropical forest soil: effects of atmospheric carbon dioxide enrichment and nitrogen addition. J Soils Sediments 10:730-738

Liu LL, Greaver TL (2009) A review of nitrogen enrichment effects on three biogenic GHGs: the $\mathrm{CO}_{2}$ sink may be largely offset by stimulated $\mathrm{N}_{2} \mathrm{O}$ and $\mathrm{CH}_{4}$ emission. Ecol Lett 12:1103-1117

López-Vicente M, Poesen J, Navas A, Gaspar L (2011) Predicting runoff and sediment connectivity and soil erosion by water for different land-use scenarios in the Spanish Pre-Pyrenees. Catena. doi:10.1016/j.catena.2011.01.001

Magnani F, Mencuccini M, Borghetti M et al (2007) The human footprint in the carbon cycle of temperate and boreal forests. Nature 447:848-850

Mahecha MD, Reichstein M, Carvalhais N et al (2010) Global convergence in the temperature sensitivity of respiration at ecosystem level. Science 329:838-840

Mahler BJ, Winkler M, Bennett P, Hillis DM (1998) DNA-labelled clay: a sensitive new method for tracing particle transport. Geology 26:831-834

Mao XA, Xu ZH, Luo RS, Mathers NJ, Zhang YH, Saffigna PG (2002) Nitrate in soil humic acids revealed by nitrogen-14 nuclear magnetic resonance spectroscopy. Aust J Soil Res 40:717-726

Martens-Habbena W, Berube PM, Urakawa H, de la Torre J, Stahl DA (2009) Ammonia oxidation kinetics determine niche separation of nitrifying Archaea and Bacteria. Nature 461:976-979

Martínez-Carreras N, Krein A, Gallart F, Iffly JF, Pfister L, Hoffmann L, Owens PN (2010) Assessment of different colour parameters for discriminating potential suspended sediment sources and provenance: a multi-scale study in Luxembourg. Geomorphology 118:118-129

Mathers NJ, Mao XA, Xu ZH, Saffigna PG, Berners-Price SJ, Perera MCS (2000) Recent advances in applications of ${ }^{13} \mathrm{C}$ and ${ }^{15} \mathrm{~N}$ NMR spectroscopy to soil organic matter studies. Aust J Soil Res 38:769-787

McConnachie JL, Petticrew EL (2006) Tracing organic matter sources in riverine suspended sediment: implications for sediment transfers. Geomorphology 79:13-26

McCulloch M, Fallon S, Wyndham T, Hendy E, Lough J, Barnes D (2003) Coral record of increased sediment flux to the inner Great Barrier Reef since European settlement. Nature 421:727-730

Megonigal JP, Guenther AB (2008) Methane emissions from upland forest soils and vegetation. Tree Physiol 28:491-498

Middelkoop H, Erkens G, van der Perk M (2010) The Rhine Delta - a record of sediment trapping over timescales from millenia to decades. J Soils Sediments 10:628-639

Middleton HE (1930) Properties of soils which influence soil erosion. United States Department of Agriculture, Technical Bulletin 178, USDA

Milliman JD, Farnsworth KL (2011) River Discharge to the Coastal Ocean. Cambridge University Press

Min SK, Zhang XB, Zwiers FW, Hegerl GC (2011) Human contribution to more-intense precipitation extremes. Nature 470:378-381

Mitchell A, Romano GH, Groisman B, Yona A, Dekel E et al (2009) Adaptive prediction of environmental changes by microorganisms. Nature 460:20-224

Moriasi DN, Steiner JL, Arnold JG (2011) Sediment measurement and transport modeling: impact of riparian and field strip buffers. J Environ Qual 40:807-814

Muir DCG, Howard PH (2006) Are there other persistent organic pollutants? A challenge for environmental chemists. Environ Sci Technol 40:7157-7166

Netzband A, Reincke H, Bergemann M (2002) The River Elbe: a case study for the ecological and economical chain of sediments. J Soils Sediments 2:112-116
Nunny RS, Stone P, Walling DE (2006) Land use change, sediment fluxes and reef conservation in Belize, Central America. In: Owens PN, Collins AJ (eds) Soil Erosion and Sediment Redistribution in River Catchments: Measurement, Modelling and Management. CAB International, Wallingford, pp 264-271

Ostro B, Broadwin R, Green S, Feng WY, Lipsett M (2006) Fine particulate air pollution and mortality in nine California counties: results from CALFINE. Environ Health Perspect 114:29

Owens PN (2005a) Conceptual models and budgets for sediment management at the river basin scale. J Soils Sediments 5: 201-212

Owens PN (2005b) Soil erosion and sediment fluxes in river basins: the influence of anthropogenic activities and climate change. In: Lens P, Grotenhuis T, Malina G, Tabak H (eds) Soil and Sediment Remediation. IWA Press, London, pp 418-433

Owens PN (2009) Adaptive management frameworks for natural resource management at the landscape-scale: implications and applications for sediment resources. J Soils Sediments 9:578-593

Owens PN, Walling DE (2003) Temporal changes in the heavy metal and phosphorus content of suspended sediment transported by Yorkshire rivers, UK over the last 100 years, as recorded by floodplain deposits. Hydrobiologia 494:185-191

Owens PN, Blake WH, Petticrew EL (2006) Changes in sediment sources following wildfire in mountainous terrain: a paired catchment approach, British Columbia, Canada. Water Air Soil Poll Focus 6:637-645

Owens PN, Duzant J, Deeks LK, Wood GA, Morgan RPC, Collins AJ (2007) Evaluation of contrasting buffer features within an agricultural landscape for reducing sediment and particulate phosphorus delivery to surface waters. Soil Use Management 23(suppl 1):65-175

Owens PN, Petticrew EL, van der Perk M (2010) Sediment response to catchment disturbances. J Soils Sediments 10:591-596

Pan KW, Xu ZH, Blumfield TJ, Tutua S, Lu MX (2008) In situ mineral ${ }^{15} \mathrm{~N}$ dynamics and fate of added ${ }^{5} \mathrm{NH}_{4}{ }^{+}$in hoop pine plantation and adjacent native forest of subtropical Australia. J Soils Sediments 8:398-405

Parkinson D-R, Dust JM (2010) Overview of the current status of sediment chemical analysis: trends in analytical techniques. Environ Rev 18:37-59

Parsons AJ, Foster IDL (2011) What can we learn about soil erosion from the use of ${ }^{137} \mathrm{Cs}$ ? Earth Sci Rev. doi:10.1016/ j.earscirev.2011.06.004

Petticrew EL (2009) Thirty years of sediment-water science: history, trends and future directions. Marine Freshwater Res 60:611-618

Petticrew EL, Albers SJ (2010) Salmon as biogeomorphic agents: temporal and spatial effects on sediment quantity and quality in a northern British Columbia spawning channel. In: Banasik K, Horowitz AJ, Owens PN, Stone M, Walling DE (eds) Sediment Dynamics for a Changing Future. IAHS Publ 337:251-257

Petticrew EL, Owens PN, Giles TR (2006) Wildfire effects on the composition and quantity of suspended and gravel stored sediments. Water Air Soil Poll Focus 6:647-656

Piao SL, Fang JY, Ciais P, Peylin P, Huang Yet al (2009) The carbon balance of terrestrial ecosystems in China. Nature 458:1009-1013

Piao SL, Ciais P, Huang Yet al (2010) The impacts of climate change on water resources and agriculture in China. Nature 467:43-51

Phillips JM, Walling DE (1995) An assessment of the effects of sample collection, storage and resuspension on the representativeness of measurements of the effective particle size distribution of fluvial suspended sediment. Water Res 29:2498-2508

Polyakov VO, Nearing MA (2004) Rare earth element oxides for tracing sediment movement. Catena 55:255-276

Raghoebarsing AA, Pol A, van de Pas-Schoonen KT et al (2006) A microbial consortium couples anaerobic methane oxidation to denitrification. Nature 440:918-923 
Ravishankara AR, Daniel JS, Portmann RW (2009) Nitrous oxide (N2O): The dominant ozone-depleting substance emitted in the 21 st century. Science 326:123-125

Reich PB (2009) Elevated $\mathrm{CO}_{2}$ reduces losses of plant diversity caused by nitrogen deposition. Science 326:1399-1402

Reid MKR, Spencer KL, Shotbolt L (2011) An appraisal of microwave-assisted Tessier and BCR sequential extraction methods for the analysis of metals in sediments and soils. J Soils Sediments 11:518-528

Rex JF, Petticrew EL (2008) Delivery of marine-derived nutrients to streambeds by Pacific salmon. Nature Geosci 1:20-23

Rockström J, Steffen W, Noone K, Persson A, Chapin FS et al (2009) A safe operating space for humanity. Nature 461:472-475

Rotenberg E, Yakir D (2010) Contribution of semi-arid forests to the climate system. Science 327:451-454

Saari H-K, Schmidt S, Castaign P, Blanc G, Sautour B, Masson O, Cockran JK (2010) The particulate ${ }^{7} \mathrm{Be} /{ }^{210} \mathrm{~Pb}_{\mathrm{xs}}$ and ${ }^{234} \mathrm{Th} /{ }^{210} \mathrm{~Pb}$, active ratios as tracers for tidal-to-season particle dynamics in the Gironde estuary (France): implications for the budget of particle associated contaminants. Sci Total Environ 408:4784-4794

Salant NL (2011) "Sticky business": the influence of streambed periphyton on particle deposition and infiltration. Geomorphology 126:350-363

Salomons W (2005) Sediments in the catchment-coast continuum. J Soils Sediments 5:2-8

Scheffer M, Bascompte J, Brock WA, Brovkin V, Carpenter SR et al (2009) Early-warning signals for critical transitions. Nature 461:53-59

Schiermeier Q (2010) The real holes in climate science. Nature 463:284-287

Schulze ED, Luyssaert S, Ciais P, Freibauer A, Janssens IA et al (2009) Importance of methane and nitrous oxide for Europe's terrestrial greenhouse-gas balance. Nature Geosci 2:842-850

Sigua GC, Coleman SW (2010) Spatial distribution of soil carbon in pastures with cow-calf operation: effects of slope aspect and slope position. J Soils Sediments 10:240-247

Smith HG, Sheridan GJ, Lane PNJ, Nyman P, Haydon S (2011) Wildfire effects on water quality in forest catchments: a review with implications for water supply. J Hydrol 396:170-192

Spencer KL, Suzuki K, Hillier S (2011) The development of rare earth element-labelled potassium-depleted clays for use as cohesive sediment tracers in aquatic environments. J Soils Sediments. doi:10.1007/s11368-011-0377-9

Stevens CJ, Quinton JN (2008) Investigating source areas of eroded sediments transport in overland flow using rare earth element tracers. Catena 74:31-36

Steward A, Reedyk S, Franz B, Fomradas K, Hilliard C, Hall S (2011) A planning tool for design and location of vegetative buffers on watercourses in the Canadian prairies. $\mathrm{J}$ Water Soil Conserv 66:97A-103A

Strand AE, Pritchard SG, McCormack ML, Davis MA, Oren R (2008) Irreconcilable differences: fine-root life spans and soil carbon persistence. Science 319:456-458

Sun FF, Kuang YW, Wen DZ, Xu ZH, Li JL, Zuo WD, Li J, Hou EQ (2010) Long-term tree growth rate, water use efficiency and tree ring nitrogen isotope composition of Pinus massoniana in response to global climate change and local nitrogen deposition in southern China. J Soils Sediments 10:1453-1465

Sutherland RA (2010) BCR (R)-701: a review of 10 years of sequential extraction analyses. Analytica Chimica Acta 680:10-20

Syvitski JPM, Vorosmarty CJ, Kettner AJ, Green P (2005) Impact of humans on the flux of terrestrial sediment to the global coastal ocean. Science 308:376-380

Tallberg P, Lukkari K, Raike A, Lehtoranta J, Leivuoir M (2009) Applicability of a sequential $\mathrm{P}$ extraction procedure to $\mathrm{Si}$ in sediment. J Soils Sediments 9:594-603
Tamtam F, Le Bot B, Dinh T, Mompelat S, Eurin J, Chevreuil M, Bonte P, Mouchel JM, Ayrault S (2011) A 50-year record of quinolone and suplhonamide antimicrobial agents in Seine River sediments. J Soils Sediments 11:852-859

Taylor KG, Owens PN (2009) Sediments in urban river basins: a review of sediment-contaminant dynamics in an environmental system conditioned by human activities. J Soils Sediments 9:281-303

Thonon I, Roberti JR, Middelkoop H, van der Perk M (2005) In situ measurements of sediment settling characteristics in floodplains using a LISST-ST. Earth Surf Process Landforms 30:1327-1343

Trumbore SE, Czimczic CI (2008) Geology - An uncertain future for soil carbon. Science 321:1455-1456

Verstraeten G, Poesen J, Gillijns K, Govers G (2006) The use of riparian vegetated strips to reduce river sediment loads: an overestimated control measure? Hydrol Process 20:42594267

Walling DE, Fang D (2003) Recent trends in the suspended sediment loads of the world's rivers. Global Planet Change 39:111-126

Walling DE, Owens PN, Foster IDL, Lees JA (2003) Changes in the fine sediment dynamics of the Ouse and Tweed basins in the UK over the last 100-150 years. Hydrol Process 17:3245-3269

Wang HL, Lin KD, Hou ZN, Richardson B, Gan J (2010) Sorption of the herbicide terbuthylazibe in two New Zealand forest soils amended with biosolids and biochars. J Soils Sediments 10: 283-289

Wharton G, Cotton JA, Wotton RS, Bass JAB, Heppell CM, Trimmer M, Sanders IA, Warren LL (2006) Macrophytes and suspensionfeeding invertebrates modify flows and fine sediment in the Frome and Piddle catchments, Dorset (UK). J Hydrol 330: $170-184$

White SM, Apitz SE (2008) Conceptual and strategic frameworks for sediment management at the river basin scale. In: Owens PN (ed) Sustainable Management of Sediment Resources: Sediment Management at the River Basin Scale. Elsevier, Amsterdam, pp 31-53

Williams ND, Walling DE, Leeks GJL (2007) High temporal resolution in situ measurement of the effective particle size characteristics of fluvial suspended sediment. Water Res 41:1081-1093

Wölz J, Fleig M, Schulze T, Maletze S, Lübcke-von Varel U, Reifferscheid G, Kühlers D, Braunbeck T, Brack W, Hollert H (2010) Impacts of contaminants bound to suspended particular matter in the context of flood events. J Soils Sediment 10: 1174-1185

Xing SH, Chen CR, Zhou BQ, Zhang H, Nang ZM, Xu ZH (2010) Soil soluble organic nitrogen and microbial processes under adjacent coniferous and broadleaf plantation forests. J Soils Sediments 10:748-757

$\mathrm{Xu} \mathrm{ZH}$, Chen CR (2006) Fingerprinting global climate change and forest management within rhizosphere carbon and nutrient cycling processes. Environ Sci Pollut Res 13:293-298

$\mathrm{Xu}$ ZH, Owens PN (2010) Our thanks to the editors-in-chief: Ulrich Förstner (Sediments) and Wim Salomons (Intercompartment). J Soils Sediments 10:1435

Xu ZH, Owens PN (2011) Developments and directions of the Journal of Soils and Sediments: 2011 and beyond. J Soils Sediments $11: 1-2$

$\mathrm{Xu} \mathrm{ZH}$, Ward S, Chen CR, Blumfield T, Prasolova NV, Liu JX (2008) Soil carbon and nutrient pools, microbial properties and gross nitrogen transformations in adjacent natural forest and hoop pine plantations of subtropical Australia. J Soils Sediments 8:99-105

Xu ZH, Chen CR, He JZ, Liu JX (2009) Trends and challenges in soil research 2009: linking global climate change to local long-term forest productivity. J Soils Sediments 9:83-88 
Zhang L, Xu ZH, Patel BKC (2009a) An improved method for purifying high-molecular-weight DNA from forest leaf litters suitable for PCR. J Soils Sediments 9:261-266

Zhang L, Xu ZH, Patel BKC (2009b) Culture-dependent and cultureindependent microbial investigation of bacterial community from pine litters and soil in subtropical Australia. J Soils Sediments 9:148-160
Zhao MS, Running SW (2010) Drought-induced reduction in global terrestrial net primary production from 2000 through 2009. Science 329:940-943

Zheng YM, Chen TB, He JZ (2008) Multivariate geostatistical analysis of heavy metals in top soils from Beijing, China. J Soils Sediments 8:51-58 